\title{
A cross sectional study to evaluate serum calcium levels among pregnant women and it's association with preeclampsia and delivery outcomes at tertiary care Hospital Bikaner, Rajasthan
}

\author{
Laxmi Poonia*, Swati Kochar, Shweta Chaudhary, Priyanka Gaur, Kirti Solanki
}

Department of Obstetrics and Gynecology, S.P. Medical College and P.B.M. associated group of Hospitals, Bikaner, Rajasthan, India

Received: 19 March 2021

Accepted: 12 April 2021

\author{
*Correspondence: \\ Dr. Laxmi Poonia, \\ E-mail: drlpoonia@gmail.com
}

Copyright: () the author(s), publisher and licensee Medip Academy. This is an open-access article distributed under the terms of the Creative Commons Attribution Non-Commercial License, which permits unrestricted non-commercial use, distribution, and reproduction in any medium, provided the original work is properly cited.

\begin{abstract}
Background: Hypertensive disorders of pregnancy, including preeclampsia complicates about $10 \%$ of pregnancies worldwide. Preeclampsia is one of the major cause of maternal and perinatal morbidity and mortality worldwide. According to the National Health Portal of India, the incidence of preeclampsia is reported to be about 8-10\% among pregnant women. The present study was aimed to compare mean serum calcium levels in preeclamptic and normotensive pregnant women at third trimester of gestation and assess relationship between maternal serum calcium levels, severity of disease and overall maternal and perinatal outcome.

Methods: This was a cross sectional study conducted on 200 females divided into two groups (i.e. Study and Control Group) from $1^{\text {st }}$ November 2019 to $31^{\text {st }}$ October 2020. Informed consent was obtained for subjecting. Detailed history and clinical examination were performed. Serum calcium level was measured in both groups by spectrophotometric method.

Results: Mean serum calcium level in study group (preeclamptic) was $7.84 \pm 0.74 \mathrm{mg} / \mathrm{dl}$ while in control group (normotensive) mean serum calcium level was $9.68 \pm 0.97 \mathrm{mg} / \mathrm{dl}$. Serum calcium level was significantly lower in preeclamptic women than normotensive pregnant women $(\mathrm{p}<0.001)$.Serum calcium showed significant negative correlation with systolic and diastolic blood pressure.

Conclusions: This study concludes that hypocalcaemia may have a role in aetiology of preeclampsia and adverse maternal and perinatal outcome. Thus intake of calcium supplements may help in reduction of incidence of preeclampsia especially in a population of a developing country.
\end{abstract}

Keywords: Calcium Level, Diastolic BP, Systolic BP, Preeclampsia

\section{INTRODUCTION}

Hypertensive disorders of pregnancy, including preeclampsia complicates about $10 \%$ of pregnancies worldwide. ${ }^{1}$ According to the National Health Portal of India, the incidence of preeclampsia is reported to be about $8-10 \%$ among pregnant women. ${ }^{2}$ Preeclampsia is a multi-systemic disorder of pregnancy, with the clinical diagnostic features of hypertension and proteinuria. Preeclampsia is defined as systolic blood pressure 140 $\mathrm{mmHg}$ or greater and diastolic blood pressure $90 \mathrm{mmHg}$ or greater, documented on two occasions atleast 4 hours apart with proteinuria $(>300 \mathrm{mg} / 24 \mathrm{hrs}$ ) in a previously normotensive and nonproteinuric patient. It occurs after 20 weeks of gestation and can present as last as 4-6 weeks postpartum. ${ }^{3}$ Although the cause of this disorder is still unknown. The clinical spectrum of preeclampsia ranges from mild to severe.

Preeclampsia can complicate pregnancy and lead to both maternal and fetal complications. ${ }^{4}$ Maternal complications including eclampsia, HELLP syndrome 
(hemolysis, elevated liver enzymes, low platelet count), cardiac failure, pulmonary edema, disseminated intravascular coagulation and CNS abnormalities. ${ }^{5}$ Perinatal complications are premature birth, intrauterine growth restriction, birth asphyxia and intrauterine death. ${ }^{6}$ Previous history of preeclampsia, preexisting diabetes, multiple pregnancies, nulliparity and advanced maternal age ( $\geq 35$ years) have been reported to increase the risk of preeclampsia. $^{7,8}$

Pregnancy is a period of increasing metabolic demands compounded by requirements of a growing foetus. Pregnant women in developing countries have been reported to consume diets deficient in essential minerals like calcium. Calcium supplementation during pregnancy is known to decrease incidence as well as severity of gestational hypertension, preeclampsia, eclampsia and also neonatal morbidity and mortality, as well as preterm births, especially in developing countries, although the impact varies according to the baseline calcium intake and other prevailing risk factors in the population. ${ }^{9-12}$ The underlying mechanism can be explained by reduction in parathyroid calcium release and intracellular calcium concentration, in woman taking calcium supplementation during pregnancy, thereby reducing smooth muscle contractility and promoting vasodilatation and hence, decreasing the risk and or severity of hypertensive disorder of pregnancy. A dietary intake of $1200 \mathrm{mg} /$ day of calcium for pregnant women is recommended by WHO and the Food and Agriculture Organization of the United Nations (FAO) whereas in pregnant women with low dietary calcium intake the recommended calcium is $1.5 \mathrm{~g}$ to 2 g daily. ${ }^{13}$

The purpose of this study was to compare mean serum calcium levels of preeclamptic and normotensive pregnant women, impact of maternal serum calcium levels on severity of hypertensive disorder of pregnancy and it's effect on overall outcome of pregnancy.

This would help us to formulate strategies to counsel high risk women in antenatal period for the importance of increase intake of food rich in calcium, e.g. milk and milk products and calcium supplementation. Such simple prophylactic measures may reduce the maternal and fetal morbidity and mortality associated with this serious obstetric complication.

\section{METHODS}

The study was a cross-sectional study conducted at Department of Obstetrics and Gynecology, Sardar Patel Medical College, Bikaner, Rajasthan from $1^{\text {st }}$ November 2019 to $31^{\text {st }}$ October 2020.

Two hundred women, who gave consent for inclusion in study were enrolled 100 in study group (preeclamptic) and 100 in control group (normotensive). All participants were in third trimester of pregnancy, parity less than five, singleton pregnancy and age between 18 to 35 years. Women with essential hypertension, asthma, hematological disorders, cardiac disease, liver and kidney disease excluded from our study. The serum calcium levels for both the groups were determined by spectrophotometric method by Beckman Coulter X2-5 Automatic Analyzer. The reagent used by the system for calcium determination was CA2 300 calcium reagent. These patients were followed till term and fetal outcome were recorded.

\section{Data analysis}

To collect required information from eligible patients a prestructured pretested Proforma was used. For data analysis Microsoft excel and statistical software SPSS were used and data were analyzed with the help of frequencies, figures, proportions, measures of central tendency and appropriate statistical test.

\section{RESULTS}

Table 1 shows no significant difference in demographic characteristics of study group and control group. In our study majority of cases were in age of 21-25 years $(42.5 \%)$; Illiterate and educated upto primary level $(60.5 \%)$; belonged to middle socioeconomic status $(52 \%)$ and from rural area (52\%). In the study group $67 \%$ of women were primigravida while only $58 \%$ women were primi in control group. This difference was also found statistically insignificant $(\mathrm{p}>0.05)$.

Table 2 shows the mean BMI was significantly higher in preeclamptics than normotensive. Mean systolic and diastolic blood pressure was significantly higher in study group compared to control group $(p<0.001)$. The fetal birth weight was significantly less in preeclamptic women than normotensive women.

Table 3 shows the mean serum calcium and uric acid levels in both the groups. The serum calcium concentration was significantly lower in preeclamptic group compared to normotensive group. Serum uric acid level was significantly higher in preeclamptic women than normotensive women.

Table 4 shows correlation of calcium level with diastolic blood pressure and proteinuria in preeclamptics group. In the present study, mean serum calcium level in diastolic blood pressure $>110 \mathrm{mmHg}$ group was lower than diastolic blood pressure $<100 \mathrm{mmHg}$ group $(7.21 \pm 0.46 \mathrm{vs}$ $8.08 \pm 0.72 \mathrm{mg} / \mathrm{dl})$. A significant negative correlation was found between serum calcium level and diastolic blood pressure.

Mean calcium level in proteinuria +1 was $8.10 \pm 0.47 \mathrm{mg} / \mathrm{dl}$, in proteinuria +2 mean calcium level was $8.22 \pm 0.22 \mathrm{mg} / \mathrm{dl}$ and in proteinuria $>+3$ group mean calcium level was $7.44 \pm 0.86 \mathrm{mg} / \mathrm{dl}$. 
Table 1: Distribution of cases according socio-demographic profile.

\begin{tabular}{|c|c|c|c|c|c|c|}
\hline \multirow{2}{*}{ Characteristics } & \multicolumn{2}{|c|}{ Study group } & \multicolumn{2}{|c|}{ Control group } & \multicolumn{2}{|c|}{ Total } \\
\hline & No. & $\%$ & No. & $\%$ & No. & $\%$ \\
\hline \multicolumn{7}{|c|}{ Age group (years) } \\
\hline $18-20$ & 27 & 27.0 & 19 & 19.0 & 46 & 23.0 \\
\hline $21-25$ & 40 & 40.0 & 45 & 45.0 & 85 & 42.5 \\
\hline $26-30$ & 19 & 19.0 & 23 & 23.0 & 42 & 21.0 \\
\hline $31-35$ & 14 & 14.0 & 13 & 13.0 & 27 & 13.5 \\
\hline \multicolumn{7}{|c|}{ Educational status } \\
\hline Illiterate & 38 & 38 & 22 & 22 & 60 & 30.0 \\
\hline Primary & 32 & 32 & 29 & 29 & 61 & 30.5 \\
\hline Middle & 18 & 18 & 30 & 30 & 48 & 24.0 \\
\hline Secondary & 10 & 10 & 14 & 14 & 24 & 12.0 \\
\hline Graduate & 2 & 2 & 4 & 4 & 6 & 3.0 \\
\hline Post graduate & 0 & 0 & 1 & 1 & 1 & 0.5 \\
\hline \multicolumn{7}{|l|}{ Residential area } \\
\hline Rural & 55 & 55.0 & 49 & 49.0 & 104 & 52.0 \\
\hline Urban & 45 & 45.0 & 51 & 51.0 & 96 & 48.0 \\
\hline \multicolumn{7}{|c|}{ Socioeconomic status } \\
\hline Lower & 31 & 31.0 & 27 & 27.0 & 58 & 29.0 \\
\hline Middle & 53 & 53.0 & 51 & 51.0 & 104 & 52.0 \\
\hline Upper & 16 & 16.0 & 22 & 22.0 & 38 & 19.0 \\
\hline \multicolumn{7}{|l|}{ Gravida } \\
\hline Primi & 67 & 67.0 & 58 & 58.0 & 125 & 62.5 \\
\hline Multi & 33 & 33.0 & 42 & 42.0 & 75 & 37.5 \\
\hline
\end{tabular}

Table 2: Maternal and perinatal clinical characteristics of study population.

\begin{tabular}{|c|c|c|c|c|c|c|}
\hline \multirow{2}{*}{ Variables } & \multicolumn{2}{|c|}{ Study group } & \multicolumn{2}{|c|}{ Control group } & \multirow[b]{2}{*}{$\mathbf{t}$} & \multirow{2}{*}{ P value } \\
\hline & Mean & SD & Mean & SD & & \\
\hline BMI $\left(\mathrm{kg} / \mathbf{m}^{2}\right)$ & 24.50 & 3.75 & 22.32 & 2.89 & 4.605 & $<0.001(\mathrm{~S})$ \\
\hline Systolic BP (mmHg) & 156.78 & 14.11 & 118.70 & 6.61 & 24.444 & $<0.001(\mathrm{~S})$ \\
\hline Diastolic BP (mmHg) & 102.46 & 9.05 & 76.90 & 4.65 & 25.130 & $<0.001(\mathrm{~S})$ \\
\hline Birth Weight (kg) & 2.47 & 0.52 & 2.68 & 0.40 & 3.290 & $<0.001(\mathrm{~S})$ \\
\hline
\end{tabular}

Table 3: Mean serum concentration of calcium and uric acid in study and control groups.

\begin{tabular}{|lllllll|}
\hline & \multicolumn{2}{l}{ Study group } & \multicolumn{3}{c}{ Control group } & \multicolumn{2}{c|}{ T value } \\
\hline Serum Calcium $(\mathbf{m g} / \mathbf{d l})$ & Mean & SD & Mean & SD & & P vales \\
\hline Uric Acid $(\mathbf{m g} / \mathbf{d l})$ & 7.84 & 0.74 & 9.68 & 0.97 & 15.156 & $<0.001(\mathrm{~S})$ \\
\hline
\end{tabular}

Table 4: Correlation of calcium level with diastolic BP and proteinuria in study group.

\begin{tabular}{|llllll|}
\hline Diastolic BP $(\mathbf{m m H g})$ & Mean calcium $(\mathrm{mg} / \mathrm{dl})$ & SD & Proteinuria & Mean calcium $(\mathrm{mg} / \mathrm{dl})$ & SD \\
\hline $\mathbf{1 0 0}$ & 8.08 & 0.72 & +1 & 8.10 & 0.47 \\
\hline $\mathbf{1 0 1 - 1 1 0}$ & 7.41 & 0.46 & +2 & 8.22 & 0.22 \\
\hline $\mathbf{> 1 1 0}$ & 7.21 & 0.46 & $\geq+3$ & 7.44 & 0.86 \\
\hline
\end{tabular}

\section{DISCUSSION}

Preeclampsia is a pregnancy specific complication associated with increased maternal and perinatal morbidity and mortality. Hypertension during pregnancy occurs more often in women exposed to the chorionic villi for the first time (primigravida); women with greater BMI in pregnancy. In preeclampsia, there is oxidative stress, inflammation, widespread vasospasm, ischemia and cellular hypoxia leading to endothelial dysfunction. 
This cellular injury results in influx of calcium ions into the cell leading to increased intracellular ions and loss of calcium homeostasis.

Thus, serum calcium appears to play an important role in the development of preeclampsia and it can evolve as a sensitive test for early detection of this disorder. It was observed that with increasing severity of preeclampsia measured in terms of increasing diastolic blood pressure and increasing proteinuria, the serum calcium levels were gradually decreasing. These results similar to study conducted by Rashid et al. ${ }^{14}$

In our study group out of total 100 cases, 25 women had severe preeclampsia $(\mathrm{BP}>160 / 110 \mathrm{mmHg})$ and 75 women had mild preeclampsia.

Serum calcium level was much lower in severe preeclampsia group than in mild preeclampsia group. This is similar to study done by Kanagal et al and Chaudhari et al. ${ }^{15,16}$

Hypertensive women have higher risk of Intrauterine growth restriction (IUGR) and intrauterine asphyxia due to uteroplacentation insufficiency. These patients are also at risk of accidental antepartum hemorrhage which can lead to intrauterine fetal death. WHO recommendation in 2011 found a higher risk of preeclampsia in pregnant women who had a low dietary intake of calcium. It recommended supplementation of such women with calcium. A Cochrane review further supported the WHO recommendation by reiterating that supplementation of calcium in pregnancy is associated with a significant reduction in the risk of preeclampsia.

\section{CONCLUSION}

This study was conducted to estimate the serum calcium levels in pregnant women and find out it's association with preeclampsia. The estimation of serum calcium, which is relatively cheap and safe investigation, can be used as a cost effective screening tool for early prediction of the disease. Our study shows a significant reduction of serum calcium level in preeclamptics compared to normotensive. This support the hypothesis that hypocalcaemia may have a role in the aetiology of preeclampsia and adverse maternal and perinatal outcome. Thus intake of supplements, mainly calcium may help in the reduction of incidence of preeclampsia especially in a population of a developing country like ours where the nutrition is poor.

Funding: No funding sources Conflict of interest: None declared

Ethical approval: The study was approved by the Institutional Ethics Committee

\section{REFERENCES}

1. Duley L. The global impact of preeclampsia and eclampsia. Semin Perinatol. 2009;33(3):130-7.

2. Khan KS, Wojdyla D, Say L, Gülmezoglu AM, Van Look PF. WHO analysis of causes of maternal death: a systematic review. Lancet. 2006;367(9516):106674.

3. Committee on Obstetric Practice. Emergent Therapy for Acute Onset, Severe Hypertension with Preeclampsia or Eclampsia. Committee Opinion No. Zeeman GG, Dekker GA, Van Geijn HP, Kraayan Brink AA. Endothelial function in normal and Preeclamptic pregnancy: a hypothesis. Eur J Obstel Gynecol Raprod Biol. 1992;43:113-22.

4. American College of Obstetricians and Gynecologists (ACOG). 2011.

5. American College of Obstetricians and Gynecologists; Task Force on Hypertension in Pregnancy. Hypertension in pregnancy. Report of the American College of Obstetricians and Gynecologists' Task Force on Hypertension in Pregnancy. Obstet Gynecol. 2013;122(5):1122-31.

6. Ananth CV, Basso O. Impact of pregnancy-induced hypertension on stillbirth and neonatal mortality. Epidem. 2010; 21(1):118-23.

7. Serhal P, Craft I. Immune Basis for Preeclampsia: Evidence From Oocyte Recipients. The Lancet. 1987;330(8561):744.

8. Duckitt K, Harrington D. Risk factors for preeclampsia at antenatal booking: systematic review of controlled studies. BMJ. 2005;330(7491):565.

9. Imdad A, Jabeen A, Bhutta ZA. Role of calcium supplementation during pregnancy in reducing risk of developing gestational hypertensive disorders: a metaanalysis of studies from developing countries. BMC Public Health. 2011;11(3):S18.

10. Cetin I, Berti C, Calabrese S. Role of micronutrients in the periconceptional period. Human Reprod Update. 2010;16(1):80-95.

11. Hofmeyr GJ, Duley L, Atallah A. Dietary calcium supplementation for prevention of preeclampsia and related problems: a systematic review and commentary. BJOG. 2007;114(8):933-43.

12. Trumbo PR, Ellwood KC. Supplemental calcium and risk reduction of hypertension, pregnancy induced hypertension, and preeclampsia: an evidence-based review by the US Food and Drug Administration. Nutr Rev. 2007;65(2):78-87.

13. Pairu j, Triveni GS, Manohar A. The study of serum calcium and serum magnesium in pregnancy induced hypertension and normal pregnancy. Int J Reprod Contracept Obstet Gynecol. 2015;4(1):30-4.

14. Bushra Rashid, Mariam Malik Richard, Gul-E-Rana. Low Serum Calcium Levels in Preeclampsia. J South-Asian Fed Obstet Gynaecol. 2015;7(3):126-9.

15. Kanagal DV, Rajesh A, Rao K, Devi UH, Shetty H, Kuamri S, Shetty RK. Levels of serum calcium and magnesium in preeclamptic and normal pregnancy: 
A study from Coastal India. J Clin Diag Res. 2014;8(7):OC01-04.

16. Chaudhary RK, Niraula A, Bataju M, Baranwal KJ, Khan SA, Bhatt RD. Serum Calcium and Magnesium levels in Preeclampsia. Nat $\mathrm{J}$ Lab Med. 2018;7(4):BO01-6.
Cite this article as: Poonia L, Kochar A, Chaudhary S, Gaur P, Solankim K. A cross sectional study to evaluate serum calcium levels among pregnant women and it's association with preeclampsia and delivery outcomes at tertiary care hospital Bikaner, Rajasthan. Int J Reprod Contracept Obstet Gynecol 2021;10:2026-30. 